by Valery V. Chernykhl, Boris I. Chuvashov', Shu-Zhong Shen ${ }^{2 *}$, Charles M. Henderson ${ }^{3}$, Dong-Xun Yuan $^{4}$, and Michael H. Stephenson ${ }^{5}$

\title{
The Global Stratotype Section and Point (GSSP) for the base- Sakmarian Stage (Cisuralian, Lower Permian)
}

\author{
${ }^{1}$ Zavaritskii Institute of Geology and Geochemistry, Ural Branch, Russian Academy of Sciences, Pochtovyi per. 7, Yekaterinburg 620219, Russia \\ ${ }^{2}$ State Key Laboratory for Mineral Deposits Research and School of Earth Sciences and Engineering, Nanjing University, Nanjing 210023 , \\ China; *Corresponding author, E-mail: szshen@nju.edu.cn \\ ${ }^{3}$ Department of Geoscience, University of Calgary, Calgary, Alberta T2N 1N4, Canada \\ ${ }^{4}$ LPS, Nanjing Institute of Geology and Palaeontology and Center for Excellence in Life and Paleoenvironment, Chinese Academy of Sciences, \\ Nanjing 210008, China \\ ${ }^{5}$ British Geological Survey, Nottingham NG12 5GG, UK
}

(Received: August 13, 2019; Revised accepted: April 3, 2020)

https://doi.org/10.18814/epiiugs/2020/020059

The Sakmarian Stage represents a critical time interval because the Late Paleozoic Ice Age reached its acme during this time. After extensive studies, we herein use the First Appearance Datum (FAD) of the conodont Mesogondolella monstra within the lineage from $\mathrm{M}$. uralensis $\rightarrow \mathrm{M}$. monstra $\rightarrow$ M. manifesta at Bed $26 / 3$ of the Usolka section in the southern Urals, Russia, as the primary signal for the base-Sakmarian GSSP. The first occurrence of the conodont Sweetognathus binodosus within the lineage from Sw. aff. merrilli $\rightarrow \mathrm{Sw}$. binodosus is used as an auxiliary marker for the base of the Sakmarian Stage. An extrapolated age for this GSSP is 293.52 \pm 0.17 Ma produced by a Monte Carlo simulation based on two ash beds dated by chemical abrasion isotope dilution thermal ionization mass spectrometry (CA-ID-TIMS). The ${ }^{87} \mathrm{Sr}^{86} \mathrm{Sr}$ isotopic value based on conodont apatite for the base of the Sakmarian Stage is approximately 0.70787. Two minor negative excursions in $\delta^{13} C_{\text {carb }}$ are present at the boundary levels and the upper one is consistent with the GSSP level. The documentation of fusulinaceans, ammonoids, brachiopods and palynology also aid intercontinental and marine-terrestrial correlation. The Usolka section meets the requirements for the GSSP and a monument has been established; correlation with sections in North America and South China is also well documented.

\section{Introduction}

The Sakmarian Stage is the second stage of the Permian System, and it is one of the critical intervals of the Late Paleozoic Ice Age (LPIA). This interval represents the most widespread glacial interval of the Phanerozoic and is an excellent analog for the modern Earth's natural systems under transition from icehouse to greenhouse (Isbell et al., 2003; Fielding et al., 2008). A high-resolution international timescale is fundamental to understand past climate changes. The main purpose of this paper is to publish the Global Stratotype Section and Point (GSSP) proposal for the base of the Sakmarian Stage at the Usolka section in southern Urals, Russia, which was formally ratified by the International Union of Geological Sciences in July, 2018. This GSSP provides an important time anchor for the acme of the LPIA. Two sections were used for studying the lower boundary of the Sakmarian Stage on the western slope of the southern Urals: the section along the Usolka River and the historical Russian stratotype for the Sakmarian Stage - the Kondurovsky section (Fig. 1). Concerning the comparative characteristic of these sections, it is noteworthy that rocks of the Usolka section were deposited in an outer shelf or slope setting, whereas the Kondurovsky section rocks represent a shallow-water succession. The Kondurovsky section, proposed as an earlier GSSP candidate by Chuvashov et al. (2002), represents a thick series of deposits with abundant fossils (Davydov et al., 1997, 1999; Schiappa, 1999). However, subsequent studies of key conodont samples suggest that in situ fossils are often accompanied by reworked forms. The wide variety of paleontological remains (conodonts, ammonoids and fusulinaceans) at the Kondurovsky section (Chuvashov et al., 1993; Davydov et al., 1997, 1999; Schiappa, 1999; Chernykh, 2005, 2006), make the section useful as an auxiliary stratotype.

A section of calcareous mudstone deposits on the right bank of the Usolka River (Figs. 2-4), located near the health resort Krasnousolsky (Republic of Bashkortostan of Russia), is well known to stratigraphers since the International Congress "Permian System of the World" in 1991 (Chuvashov et al., 1991a, 1993). It served as a potential site for developing the boundary between the Carboniferous and Permian systems based on conodonts and it is herein determined to be an excellent section for defining the Sakmarian-base boundary. The section has recently become more and more widely used because it is easily accessible and contains both well-preserved conodonts (Fig. 3) and multiple ash beds with zircons dated using high-precision CA-ID TIMS dates (Fig. 4) (Chernykh, 2006; Chernykh et al., 2006; Ramezani et al., 2007; Schmitz 

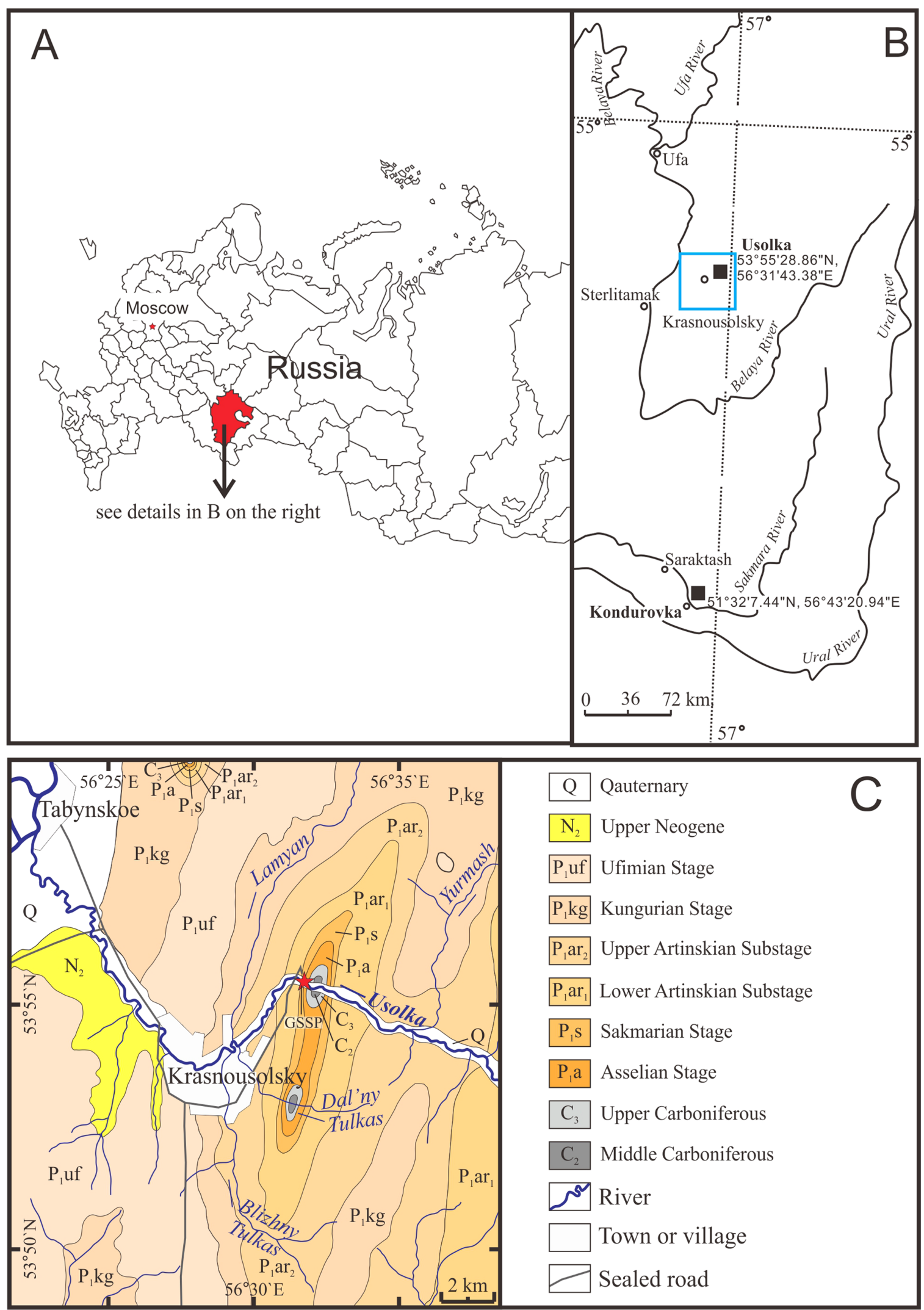

Figure 1. (A) Location of Usolka section in Republic Bashkortostan, Russia (Bashkortostan is marked in red); (B) Location of the Usolka and Kondurovsky sections; (C) Geological map, showing the studied area and the location of the GSSP section for the base of the Sakmarian Stage (indicated by red star).

and Davydov et al., 2012). A level within the Usolka section is defined herein as the GSSP for the base boundary of the Sakmarian Stage for the International Permian Time Scale. A precise duration for the underlying entire Asselian Stage has been established in this area of 




Figure 2. A picture showing the outcrop and proposed GSSP position at the Usolka section in southern Urals, Russia (Valery Chernykh for scale).

the southern Urals, Russia (Ramezani and Bowring, 2018; Shen et al., 2019).

A detailed description of the Usolka (Fig. 4) section and a lithologic column for the Kondurovsky section indicating critical conodonts around the base of the Sakmarian Stage (Fig. 5) were published previously (Chuvashov et al., 1991a, b; Zeng et al., 2012). An informal proposal was published in Permophiles (Chernykh et al., 2013) and a revised version was published subsequently (Chernykh et al., 2016) after extensive discussions within the Subcommission on Permian Stratigraphy. We herein provide the description of the Usolka section that indicates the precise level of the first occurrence of the most important conodont species, which has been studied in detail by Chernyhk (2005, 2006) (Figs. 2-4).

\section{General Characteristics of the Usolka Section}

The section on the Usolka River largely correlates with the section on the Dal'ny Tulkas stream where calcareous mudstone strata of Upper Carboniferous, Asselian, Sakmarian and Artinskian deposits are well developed and crop out.

The Gzhelian, Asselian and the lower part of the Sakmarian succession at the Usolka section were deposited in a relatively deep water setting with a low sedimentation rate based on its total thickness of 30 $\mathrm{m}$ (Fig. 2). The succession is a continuous series of deposits and contains a very well exposed Carboniferous/Permian boundary at the Usolka section (Chernykh, 2006; Chernykh et al., 2006). The Asselian and Sakmarian at the Usolka section include turbidite deposits, probably associated with storms (tempestites), which are interbedded with thinbedded carbonate mudstone containing rare bioturbation and repre- senting the background sedimentation between storm events. Slumped breccia units, and pyrite-bearing and phosphate interbeds (Fig. 2) are also present. Most of the rocks in this part of the section are rich in conodonts and we obtained more than 200 specimens per $\mathrm{kg}$ in the Asselian part. In contrast, the quantity and variety of conodonts are reduced in the Sakmarian part of the section to 25 to 50 specimens per $\mathrm{kg}$ (Fig. 3).

Traditionally, the early Cisuralian of the Usolka section was zoned by fusulinaceans and ammonoids. We here update conodont data for this interval, which spans the Asselian-Sakmarian boundary (Figs. 3, 4). The nature of sedimentary cycles and the absence of any significant tectonic disturbance and interruption testify to the continuity of sedimentation. In addition, the analysis of conodont lineages and morphologic trends within the prevailing genera exclude the possibility of any post-sedimentary processes like reworking and redeposition in this section (Chernykh, 2005, 2006). Thus, the GSSP level is located in an interval with continuous carbonate and argillaceous-carbonate deposition, accumulated without interruption. One disadvantage of the section is the relatively low abundance of other fossils, which is predictable in this slope succession. Shallow-water fusulinaceans are rare in the Asselian, ammonoids are restricted to the Upper Carboniferous, and other fusulinaceans are only found from the Sakmarian Stage; these fossils are presented in Fig. 4.

The total thickness of the lower Cisuralian at the Usolka section is more than $70 \mathrm{~m}$ (Fig. 4). The relatively condensed sedimentation and reduced thickness of the stratigraphic succession have positive and negative effects on the recovery of the conodont succession. Most importantly, a degree of condensation means the succession is enriched in some fossil groups, and in particular of conodonts at the section.

Large samples were collected and abundant conodonts were described 


\section{Usolka section}

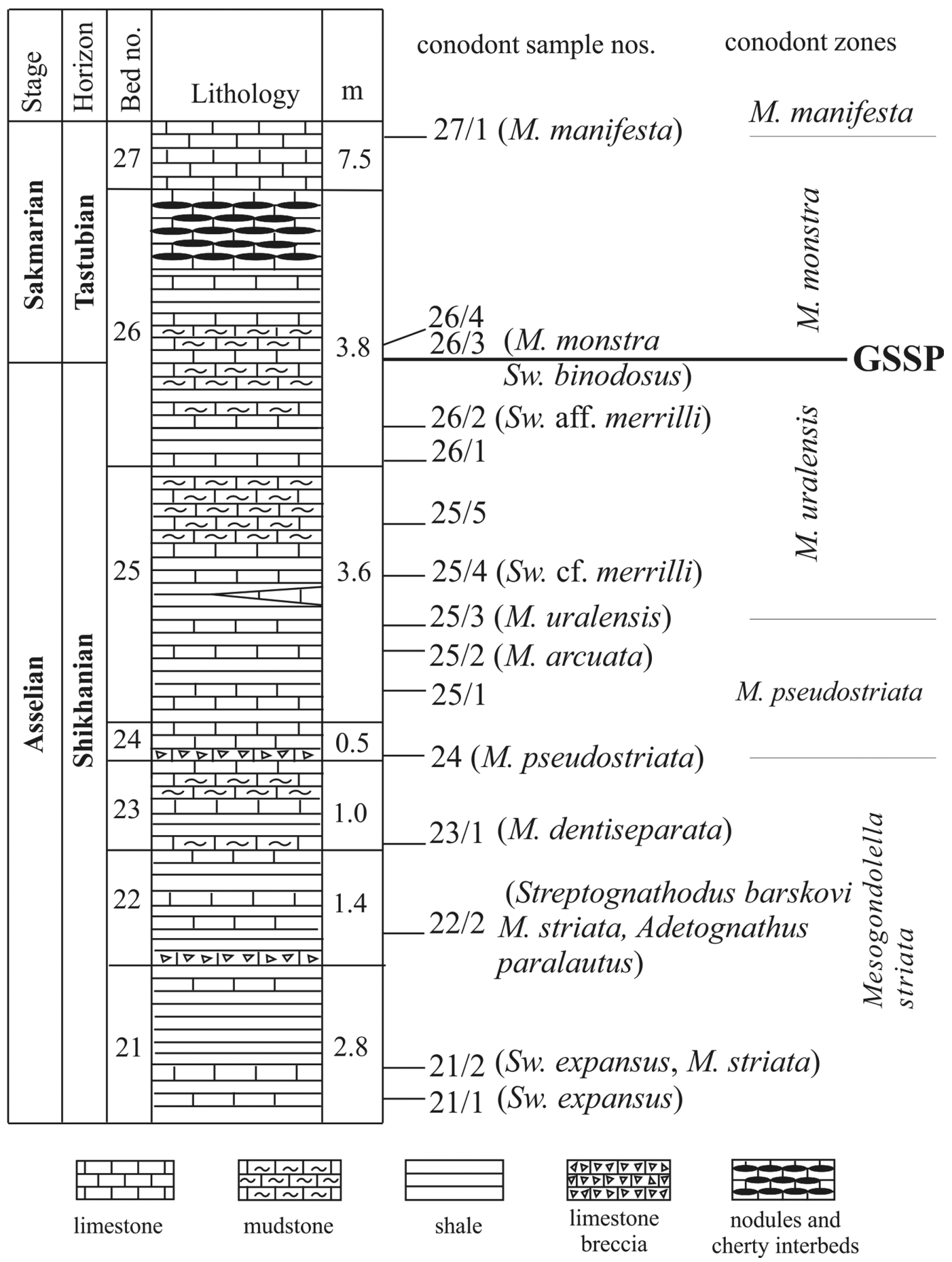

Figure 3. Stratigraphic column of the Asselian-Sakmarian interval with the characteristic species and zones of conodonts of the Usolka section.

from the sections (Chernykh, 2005, 2006), which formed the basis to interpret the two complete conodont lineages (both Mesogondolella and Sweetognathus) (Figs. 3, 6, 7). In some rocks (claystone, dolostone, silicified limestone etc.) the extraction and recovery of conodonts is difficult, thus, conodont data in these beds of the section may be limited. Therefore, we tried to replicate the conodont succession of the Usolka section by testing other sections and facies types. An expanded section could provide more information of conodont evolution lin- eages. To this effect, the section of the upper Asselian-Sakmarian interval on the right bank of the Sakmara River near the Kondurovsky settlement was studied and conodonts were investigated (Figs. 5-9).

The boundary interval between the Asselian and Sakmarian stages at the Usolka section is very well exposed along a roadside and is therefore easily accessible (Fig. 2). The detailed description of this transitional interval is provided below with sample levels and fossil lists (Figs. 3, 4). 


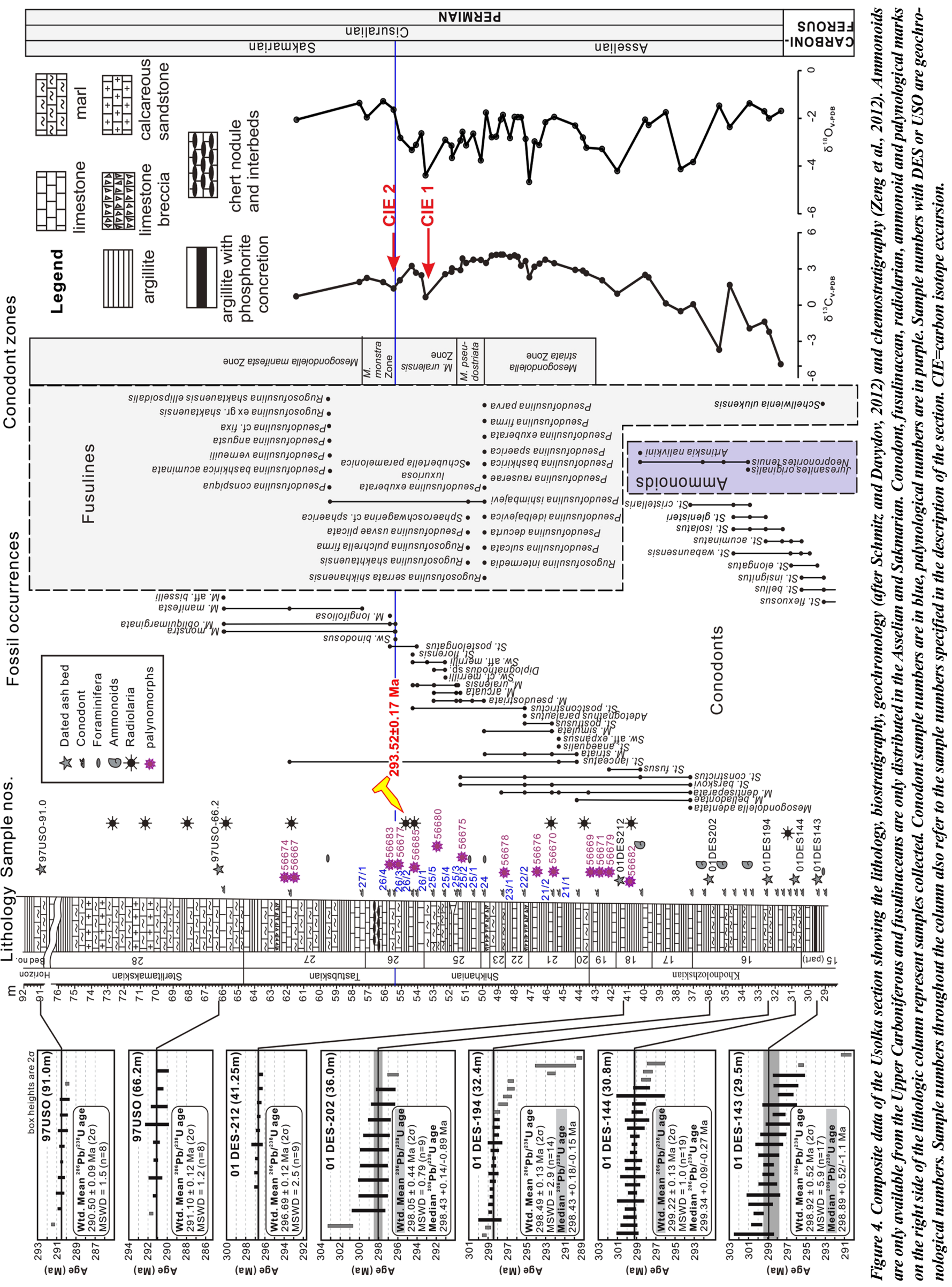


Description of the Usolka section (metres in brackets after the conodont sample numbers indicate the distance of the sample from the base of the section)

\section{Upper Asselian}

Shikhanian horizon

\section{Mesogondolella striata Zone}

Bed 21. Alternation of carbonate and clay-rich rocks. The calcareous interbeds with a thickness from 4 to $25 \mathrm{~cm}$ have greenish-grey or dark-grey color, are fine-grained to micritic. The interbeds $(4-5 \mathrm{~cm})$ of mudstone frequently have fragmental structure and are divided by dark-grey fissile argillite and marl (from 2.5 to $20 \mathrm{~cm}$ ). Oval concretions of greenish-grey marl with size from 1 to $7 \mathrm{~cm}$, and interbeds of dark-grey chert occur in some argillite levels. Fossil remains include brachiopods, bivalves, fish-scales, and conodonts. $2.8 \mathrm{~m}$.

Sample 21/1 (45.3 m) includes the following conodonts: Streptognathodus anaequalis Chernykh, St. lanceatus Chernykh, Sweetognathus aff. expansus (Perlmutter), Mesogondolella dentiseparata (Reshetkova and Chernykh).

Sample 21/2 (45.7 m) contains conodonts: Streptognathodus barskovi Kozur, St. postfusus Chernykh and Reshetkova, Mesogondolella dentiseparata (Reshetkova and Chernykh), M. simulata (Chernykh), and M. striata (Chernykh).

Bed 22. A $5-7 \mathrm{~cm}$ thick breccia bed occurs at the basal part and is composed of angular fragments of marl, $1 \mathrm{~cm}$ limestone fragments, and also of different fossil remains including crinoid ossicles, brachiopods, bryozoans, and small foraminifers. The breccia bed changes gradually to resistant bioclastic limestone $(20 \mathrm{~cm})$ that contains fragments of brachiopod shells, bryozoans and crinoid ossicles. This breccia bed is obviously a gravity flow deposit based on the very poorly sorted and angular-shaped pebbles inside. The graded bedding structure does not suggest a hiatus. The upper part of the bed is composed of brownish-light-grey micritic and argillaceous limestone with platy partings. $1.4 \mathrm{~m}$.

Sample 22/2 $(47.3 \mathrm{~m})$. The sample is selected from the detrital limestone directly above the breccia, and the following conodonts are found: Streptognathodus barskovi Kozur, St. postconstrictus Chernykh, St. postfusus Chernykh and Reshetkova, St. constrictus Reshetkova and Chernykh, Mesogondolella dentiseparata (Reshetkova and Chernykh), M. striata (Chernykh), and Adetognathus paralautus Orchard and Forster.

Bed 23. Alternation of dark grey marl with grassy-greenish spots and light-grey micritic limestone; there are layers of argillite in the middle part of the bed. $1.0 \mathrm{~m}$.

Sample 23/1 (48.8 m). The sample was selected from the brecciated marl interbed, and the conodont Mesogondolella dentiseparata (Reshetkova and Chernykh) was found.

\section{Mesogondolella pseudostriata Zone}

Bed 24. This greenish-grey breccia bed changes in thickness $(0-20 \mathrm{~cm})$, and includes angular or poorly rounded fragments of light-brownishgrey limestone with size from 1 to $2 \mathrm{~cm}$ at the base of the bed. These fragments include fossils of fusulinaceans, brachiopods and crinoid ossicles, and are surrounded by greyish-greenish marl. The breccia is friable and easily broken. It rapidly changes upward into light grey finedetrital thick-plated limestone. $0.5 \mathrm{~m}$.

Upper Asselian fusulinaceans are identified in the base of the bed. They include Rugosofusulina serrata shikhanensis Suleimanov, $R$. intermedia Suleimanov, Pseudofusulina sulcata Korzhenevsky, $P$. decurta Korzhenevsky, P. idelbajevica Korzhenevsky, P. ishimbajevi Korzhenevsky, P. rauserae Korzhenevsky, $P$. sphaerica (Beljaev), $P$. exuberata Shamov, P. exuberata luxuriosa Shamov, P. firma Shamov, and $P$. parva Beljaev.

Sample $24(49.7 \mathrm{~m})$ was taken in the first thick interlayer of limestone above the breccia. Conodonts include: Mesogondolella simulata (Chernykh), M. pseudostriata (Chernykh), and M. striata (Chernykh).

Bed 25. The large part of this bed represents brownish-grey interbedded mudstone $(1-3 \mathrm{~cm})$ with characteristic conchoidal fracture and dark grey fissile or thin-platy argillite, and rare marl. The thin interlayers of mudstone are frequently silicified. In the layer there are three interbeds (respectively from bottom to top 15, 20 and $12 \mathrm{~cm}$ ) of the brownish-light-grey bioclastic limestone; it is resistant and partially silicified with tiny foraminifers, fusulinaceans, bryozoans, crinoids, and the algae Tubiphytes sp. The thin interlayers of mudstone sometimes contain radiolarians and sponge spicules, which likely accounts for silicification of some of these layers. Rare brachiopods, small straight nautiloids, and fish bones are present in the argillite and marl. $3.6 \mathrm{~m}$.

The fusulinaceans, $\sim 0.8 \mathrm{~m}$ higher than the base of the layer, include: Pseudofusulinella usvae plicata (Shamov and Shcherbovich), Schubertella paramelonica Suleimanov, Rugosofusulina shaktauensis Suleimanov, R. pulchrella firma Suleimanov, Sphaeroschwagerina $\mathrm{cf}$. sphaerica Shcherbovich. This assemblage indicates a late Asselian age.

Sample 25/1 (50.6 m) was taken from the dark cream-colored organicdetrital limestone with visible fusulinaceans and there are conodonts including the species Mesogondolella pseudostriata.

Sample 25/2 (51.4 m): Streptognathodus barskovi Kozur, St. constrictus Reshetkova and Chernykh, Mesogondolella arcuata Chernykh, M. pseudostriata (Chernykh), M. arcuata transitional to M. uralensis.

\section{Mesogondolella uralensis Zone}

The following conodont samples are included in this zone:

Sample 25/3 (51.6 m): Mesogondolella arcuata Chernykh, M. pseudostriata (Chernykh), M. uralensis (Chernykh).

Sample 1250-9 (52.05 m): Mesogondolella uralensis (Chernykh), Streptognathodus postelongatus Wardlaw, Boardman and Nestell.

Sample 25/4 (52.3 m): Sweetognathus aff. merrilli Kozur, Sw. cf. merrilli Kozur, Diplognathodus sp.

Sample 1250-11 (52.65 m): Sweetognathus aff. merrilli Kozur (transitional with Sw. binodosus, Streptognathodus postfusus (Chernykh), Mesogondolella uralensis (Chernykh).

Sample 25/5 (53.0 m): Mesogondolella arcuata Chernykh, M. pseudostriata (Chernykh), M. uralensis (Chernykh), and Diplognathodus sp.

Bed 26: This bed comprises thin alternations of limestone, marl, and argillite. Limestone is brownish-grey and dark-grey, micritic with thicknesses of 2-5 cm and rarely up to $10 \mathrm{~cm}$. Limestone interlayers frequently are completely silicified. In the lower part of the bed, the brownish-grey and ash-grey thin platy or fissile interbeds of argillite 


\section{Kondurovsky section}

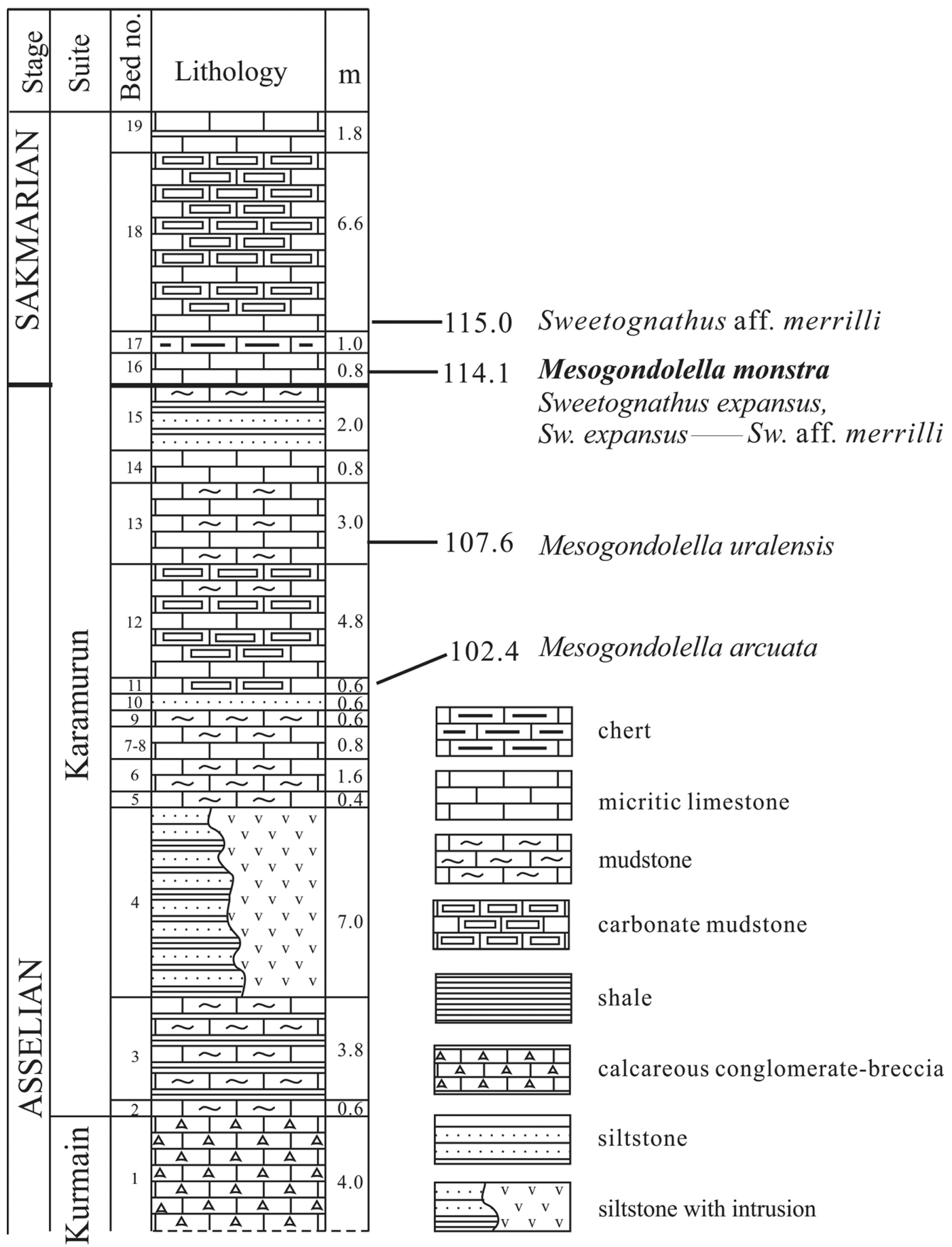

Figure 5. Stratigraphic column of the Asselian-Sakmarian interval with the characteristic species and zones of conodonts of the Kondurovsky section.

and marl attain a thickness of $15-20 \mathrm{~cm}$, and above, the thickness decreases to $5-7 \mathrm{~cm}$. A thin $(1-2 \mathrm{~cm})$ layer of bioclastic limestone, including fragments of crinoids, bryozoan, foraminifers, and the algae Tubiphytes sp., is found in the lower part of the limestone interbeds. Plant microfossils in the argillite include abundant acritarchs of satisfactory and poor preservation. $3.8 \mathrm{~m}$.

Sample 26/1 (54.0 m): Streptognathodus postelongatus Wardlaw, Boardman and Nestell, Mesogondolella uralensis (Chernykh).
Sample 26/2 (54.3 m): Streptognathodus florensis Wardlaw, Boardman and Nestell, St. postconstrictus Chernykh, Sweetognathus aff. merrilli Kozur, Mesogondolella uralensis (Chernykh).

\section{Sakmarian}

Tastubian horizon

Mesogondolella monstra Zone (and the correlative Sweetognathus 




Figure 6. Key Mesogondolella species around the Asselian-Sakmarian boundary at the Usolka and Kondorovsky sections in the southern Urals. 1. Mesogondolella striata (Chernykh); Specimen U34-8; Usolka section, Bed 22/2; 2. M. pseudostriata (Chernykh); Specimen U37-21, Usolka section, Bed 25/2; 3. M. uralensis (Chernykh); Specimen U38-7; Usolka section, Bed 25/3; 4. M. uralensis (Chernykh). Specimen K35-14, Kondurovsky section, Bed 13. 5-8. Mesogondolella striata (Chernykh): 5-Specimen U34-4; 6-Specimen U34-5; 7-Specimen U34-6; 8-Specimen U34-7; Usolka section, Bed 21/1; 9, 10. Mesogondolella pseudostriata (Chernykh): 9-Specimen U37-19; 10 - Specimen U3731; Usolka section, Bed 25/2; 11. Mesogondolella pseudostriata (Chernykh) (transitional to M. obliquimarginata (Chernykh), Specimen U37-33; Usolka section, Bed 25/2; 12-18. Mesogondolella arcuata Chernykh: 12 - Specimen U34-47; Usolka section, Bed 25-2; 13 Specimen K35-5m; 14 -Specimen K35-4; 15 -Specimen K35-2; 16-Specimen K35-1; Kondurovsky section, Bed 10; 17-Specimen K35-9; 18 - Specimen K35-10; Kondurovsky section, Bed 12; 19-23. Mesogondolella uralensis (Chernykh): 19-Specimen U38-9; 20 - Specimen U38-2; 21 -Specimen U38-6; 23 -Specimen U38-5; Usolka section, Bed-26/1; 22-Specimen U37-21; Usolka section, Beds-25/5; 24-26. Mesogondolella monstra Chernykh: 24 - Specimen K36-8; Kondurovsky section, Bed 16; 25-Specimen U32-14; 26-Specimen U32-15; Usolka section, Bed. 26/3; 27-32. Mesogondolella manifesta Chernykh; 27 - Holotype, U38-43; 28 - Specimen U38-47; 29, Specimen U3832; 30 -Specimen U38-45; 31 - Specimen U38-46; 32 - Specimen U38-44; Usolka section, Bed 27/1. 


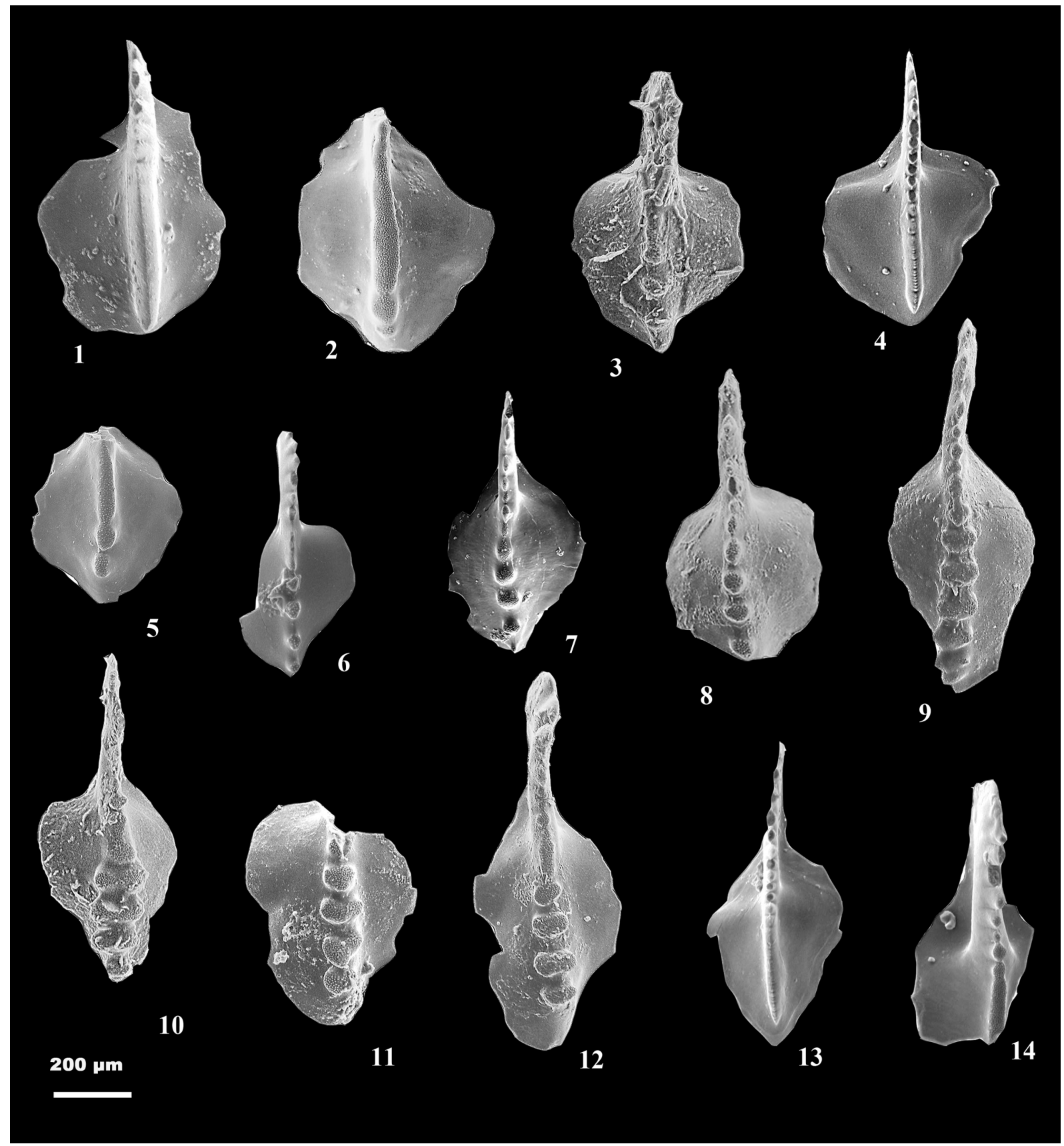

Figure 7. Key Sweetognathus species around the Asselian-Sakmarian boundary at the Usolka and Kondurovsky sections in the southern Urals. 1, 2. Sweetognathus expansus (Perlmutter): 1 - Specimen U17-25, Usolka section, Bed 14; 2 - Specimen U37A-1, Usolka section, Bed 21; 3. Sweetognathus aff. merrilli Kozur: 3 - Specimen U32A-2; 4. Sweetognathus aff. stevensi (Clark and Carr), Specimen K36-18, Kondurovsky section, Bed 18; 5 - 7. Sweetognathus aff. merrilli Kozur: 5 - Specimen K36-16 (form transitional from Sw. stevensi to Sw. aff. merrilli); Kondurovsky section, Bed 16; 6-Specimen K36-20; 7-Specimen K36-20b; Kondurovsky section, Bed 18; 8-12. Sweetognathus binodosus Chernykh: 8 - Specimen U32A-3; 9 - Holotype U32A-6; 10 - Specimen U32A-7; 11 - Specimen U32A-4; 12 - Specimen U32A-5; Usolka section, Bed 26/3; 13. Sw. aff. stevensi (Clark and Carr), the middle part of Bed 16; 14. forms transitional from Sw. aff. stevensi (Clark and Carr) to Sw. aff. merrilli Kozur, upper part of Bed 16, Kondurovsky section.

\section{binodosus Zone)}

Sample 26/3 (55.4 m): Sweetognathus binodosus Chernykh, Mesogondolella obliquimarginata (Chernykh) and M. monstra Chernykh.

Sample 26/4 (55.7 m): Streptognathodus postelongatus Wardlaw, Boardman and Nestell, Mesogondolella obliquimarginata Chernykh, and $M$. longifoliosa (Chernykh).

Bed 27. The lower $1.15 \mathrm{~m}$ is composed of brownish-grey marl with platy separation at a thickness of $3-5 \mathrm{~cm}$. The upper $4 \mathrm{~m}$ includes three interbeds of bioclastic limestone with a bed thickness up to $15 \mathrm{~cm}$, which consists of small foraminifers, bryozoans, crinoids, the algae Tubiphytes, and other fossil detritus. Tastubian fusulinaceans are determined from the limestones and include Rugosofusulina shakhtauensis ellipsoidalis Suleimanov, $R$. ex gr. shakhtauensis Suleimanov, Pseudofusulina ischimbajevi Korzhenevsky, P. baschkirica acuminata Kireeva, P. verneuili 
(Moeller), P. conspiqua Rauser-Chernousova, $P$. cf. fixa Kireeva, and $P$. angusta Kireeva. The thin $(5-10 \mathrm{~cm})$ interbeds of micritic limestone are distributed throughout the unit. $7.5 \mathrm{~m}$.

Sample 27/1 (57.4 m): Mesogondolella manifesta Chernykh.

\section{Biostratigraphy}

The above description about the lithology and the fossil zones of the Usolka section shows that the section contains continuous conodont lineages from Asselian to early Artinskian (Figs. 8, 9) and many fusulinacean fossils in the Sakmarian, thus, it is well qualified as the GSSP for the base of the Sakmarian Stage.

\section{Conodonts}

The Asselian-Sakmarian conodonts in the Usolka section, which we have used to define the GSSP for the base-Sakmarian Stage, are characterized by high frequency (from 50 and more per $\mathrm{kg}$ of sample) and good preservation. Almost all the obtained P1 elements are complete and transparent with CAI 1-1.5, without adhering particles and can be used for strontium isotope and other geochemical analyses.

Conodonts of the genus Mesogondolella are most abundant in this interval at both the Usolka and Kondurovsky sections (Chernykh, 2005, 2006). Systematic composition and stratigraphic distribution of mesogondolellids are consistent between the two sections (Figs. 3-8). The characteristic form Mesogondolella monstra, within the evolutionary lineage $M$. pseudostriata $\rightarrow M$. arcuata $\rightarrow$ M. uralensis $\rightarrow$. monstra $\rightarrow$ M. manifesta (Chernykh, 2006) (Figs. 3, 8), first appears near the traditional (on the basis of the occurrences of many species of Pseudofusulina) boundary of the Sakmarian Stage. The interval between the level of the base boundary of the Sakmarian Stage as determined by cono-



Figure 8. The evolutionary lineage of the genus Mesogondolella in the Asselian-Sakmarian transitional interval. donts $(55.4 \mathrm{~m})$ and the first former lower Sakmarian fusulinaceans $(59.2 \mathrm{~m})$, is a little less than $4 \mathrm{~m}$ in the Usolka section.

This conodont succession can be recognized in both the Usolka and Kondurovsky sections despite differences in facies, and confirms the evolutionary nature of the revealed chronomorphocline, which is used as the basis for the zonation of the transitional deposits between the upper Asselian and Sakmarian (Figs. 3-5, 8, 9). The evolutionary lineage, Mesogondolella arcuata $\rightarrow$ M. uralensis $\rightarrow$ M. monstra $\rightarrow$ M. manifesta, provides a foundation for the GSSP of the base-Sakmarian Stage. We defined the base boundary of the Sakmarian Stage with an evolutionary event - the first appearance of the characteristic species M. monstra within the chronomorphocline $M$. uralensis $\rightarrow$ M. monstra $\rightarrow$ M. manifesta (Figs. 3, 8). We have used M. monstra instead of M. uralensis as the index species of the GSSP. This is because M. uralensis is very similar to M. arcuata in some specimens (e.g., compare fig. 5.21 with fig. 5.16, fig. 5.19 with fig. 5.13 in Chernykh et al. (2016)). Both species have a robust cusp and a similar platform outline. In addition, juvenile Mesogondolella specimens usually have more discrete denticles, and gerontic specimens of Mesogondolella usually have more fused denticles. Thus, the gerontic forms of $M$. arcuata are very similar to $M$. uralensis, and the juvenile $M$. uralensis are very similar to $M$. arcuata, which could make it difficult to distinguish $M$. uralensis from $M$. arcuata. In contrast, M. monstra has a relatively smaller compressed cusp, fewer, but larger denticles, and very different platform outline, which are distinguished from $M$. uralensis (Fig. 8). Therefore, the boundary between $M$. uralensis and $M$. monstra is distinct and a clearly recognizable point. In addition, M. monstra has a much wider geographic distribution and is therefore more useful for intercontinental correlation.

As an auxiliary, we also use data about the evolutionary development of representatives of the genus Sweetognathus (Fig. 9), which can be used to approximate the base boundary of the Sakmarian (Mei et al., 2002). The first representative of this genus in the Uralian succession, Sw. aff. expansus, appears in Bed 21 at the Usolka section (upper Asselian). These forms possess the continuous undifferentiated carina with a pustulose surface. Further evolution of this conodont group follows the path of the differentiation of the carina, and leads to the appearance of $S w$. aff. merrilli, which is characterized by a few carinal nodes. The identical evolutionary lineage of this species has also been recognized in the Kondurovsky section (Fig. 9).

The level of the first appearance of Sweetognathus aff. merrilli in the Usolka section nearly coincides with the first occurrence of Mesogondolella uralensis. We found the $S w$. aff. merrilli in the upper part of Bed 25 and the lower part of Bed 26 at the Usolka section (Figs. 3, 5); this taxon represents a transitional ancestral form to $S w$. binodosus. The first occurrence of Mesogondolella uralensis at $51.6 \mathrm{~m}$ is $70 \mathrm{~cm}$ lower than the first occurrence of $S w$. aff. merrilli. In the Kondurovsky section, M. uralensis appears somewhat earlier than Sw. aff. merrilli (Fig. 4). The species $S w$. aff. merrilli may be widespread (e.g., Urals, North America, China), but care must be taken before it can be used as an auxiliary indicator of proximity to the base boundary of the Sakmarian. To correlate the Asselian/Sakmarian boundary between the southern Urals and other regions is extremely important for the GSSP. Transitional forms like Sweetognathus aff. merrilli have not been recovered from the Canadian Arctic, but the local first occurrence (FO) of Sw. binodosus is abrupt and appears close to the base of the Sakmarian Stage as defined herein (Fig. 10); thus the first occurrence of Sw. binodosus 

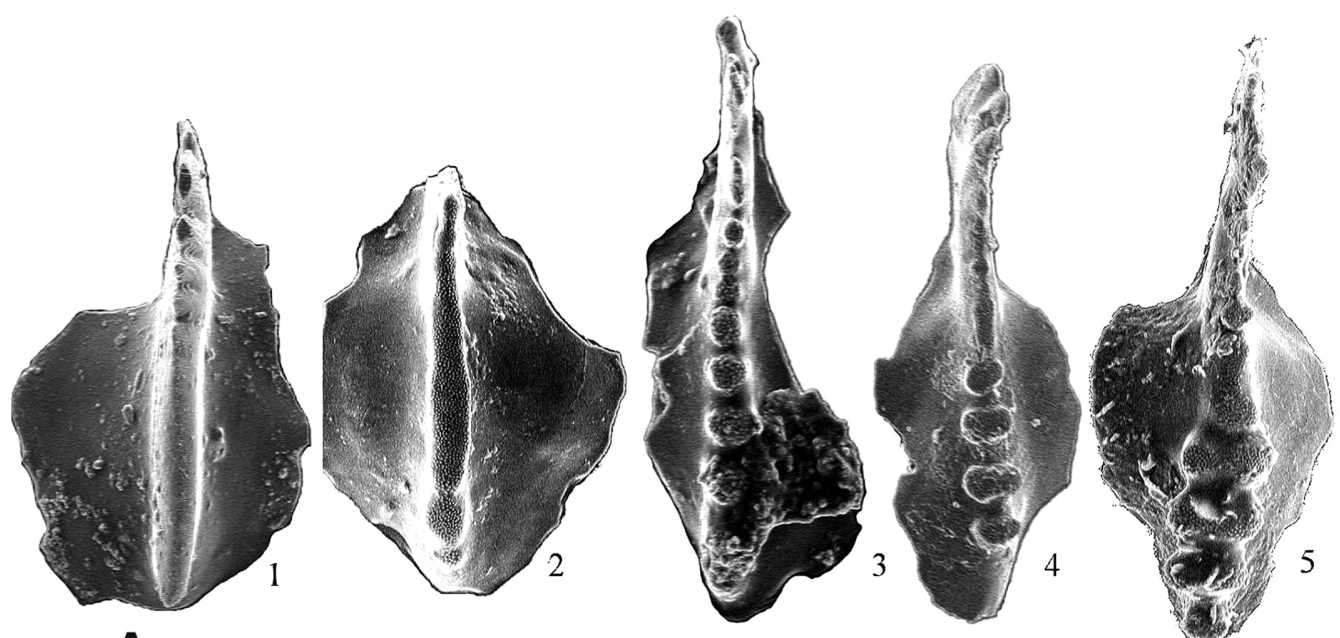

A Evolutionary trend of species of Sweetognathus in the Usolka section


B Evolutionary trend of species of Sweetognathus in the Kondurovsky section

Figure 9. A, the evolutionary lineage Sweetognathus expansus $\rightarrow$ Sw. binodosus in the Usolka section. 1 - Sw. expansus (Perlmutter), Bed 14; 2 - transitional from Sw. expansus to Sw. aff. merrilli Bed 21/2; 3 - Sw. aff. merrilli Kozur, Bed 26 (54.3 m from the beginning of section); 4, 5 - Sw. binodosus Chernykh, Bed 26 (55.4 $\mathrm{m}$ from the beginning of the section). B. The evolutionary lineage Sweetognathus aff. stevensi $\rightarrow$ Sw. aff. merrilli in the Kondurovsky section. 1 - Sw. aff. stevensi (Clark and Carr), the middle part of Bed 16; 2, 3 -forms transitional from Sw. aff. expansus (Clark and Carr) to Sw. aff. merrilli Kozur (Fig. $2 b$ is the enlarged fragment of Fig. 2a), upper part of Bed 16; 4 - Sw. aff. merrilli, Bed 18.

provides an approximate auxiliary marker for the definition of the GSSP. Figure 10 shows that the primary signal can be correlated between the Sakmarian Stage at the Usolka section (colored column in Fig. 10) and the latest Asselian to late Sakmarian Raanes Formation at the East Blind Fiord section in the Sverdrup Basin, Arctic Canada (Beauchamp and Henderson, 1994; Beauchamp et al., 2020). The comparison can be made on the basis of the conodont succession as well as the sequence stratigraphic controlled lithologic pattern. Level 1 (Fig. 10) represents a sequence boundary in which there is a significant change in sedimentation and the character of cyclothems, which are especially obvious in the underlying Belcher Channel succession. The apparent extinction of Streptognathodus (Fig. 4), including the species St. fusus, occurs a short distance above level 1 (Beauchamp et al., 2020), and the last Carboniferous holdover, Adetognathus paralautus, occurs even higher. Level 2 represents the maximum flooding surface within the Raanes Formation sequence and coincides with the FO of M. monstra and therefore the Asselian-Sakmarian boundary. It also coincides with the complete loss of cyclothems and a change in carbonate biotic assemblages (Beauchamp et al., 2020). The FO of Sw. binodosus occurs a few metres higher. (Fig. 10). At Carlin Canyon in Nevada, USA, the FO of Sweetognathus binodosus in the lower Buckskin Mountain Formation, nearly coincides with the same horizon as Mesogondolella monstra (Chernykh et al., 2016) at a level that no longer has high frequency cyclothems, which are typical of the underlying Strathearn Formation.

It is important to provide some background for the terminology (aff.) used for the sweetognathid taxa. The first nodose sweetognathids defined as Sweetognathus merrilli are found in the upper part of the Eiss limestone of the Bader Limestone Formation cyclothem in east Kansas (USA). A comparable occurrence of Sw. merrilli is recognized in the Neal Ranch Formation of the Glass Mountains in West Texas. These occurrences are older (lower Asselian) than the base of the Sakmarian Stage in the southern Urals (Henderson, 2018). Elsewhere in the USA, Wardlaw and Davydov (2000) showed results of a fusulinacean study that provides a basis for correlation of the base boundary of the 


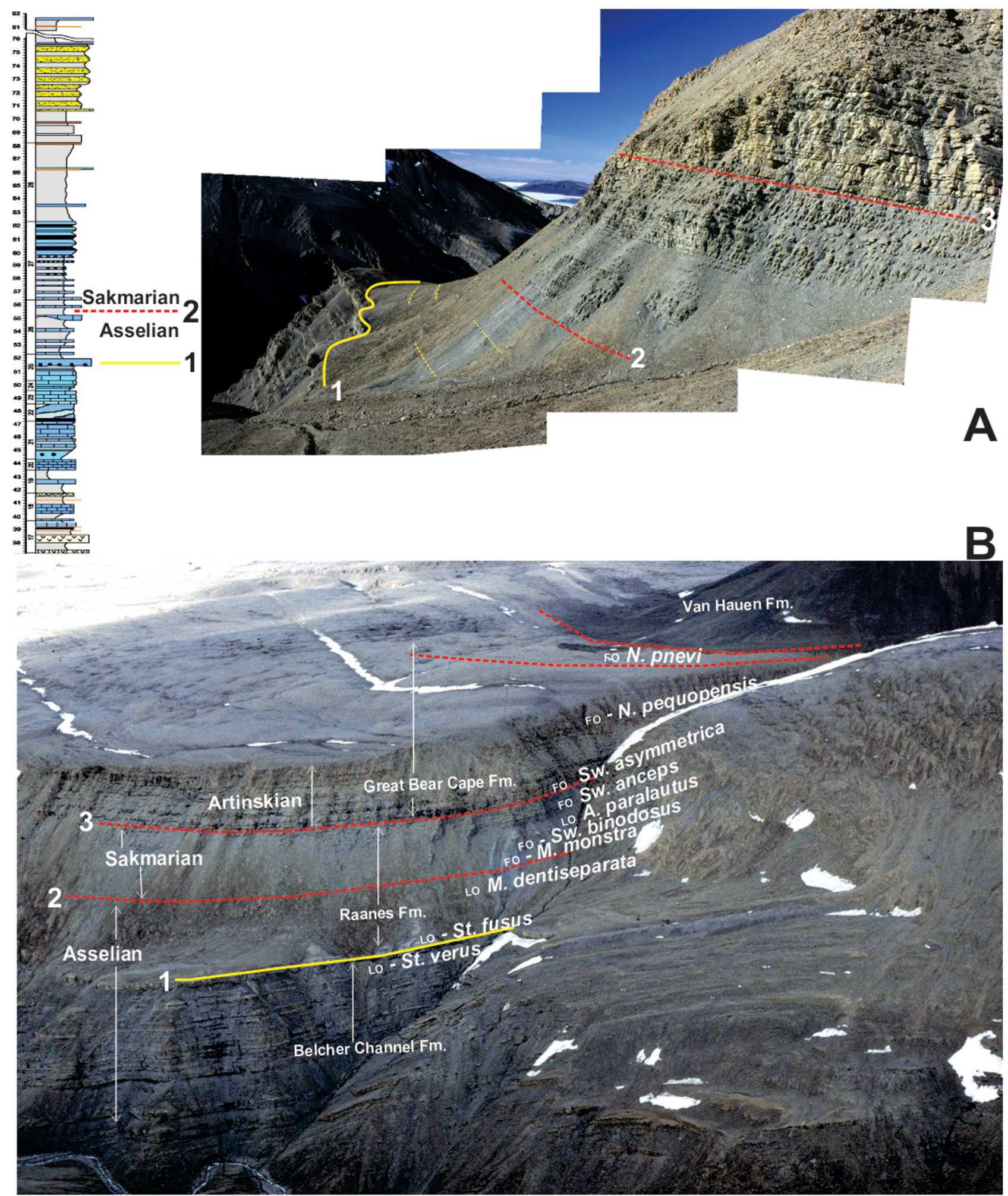

Figure 10. Two views of the East Blind Fiord section in the Canadian Arctic (78 $24^{\prime} \mathrm{N}$; $\left.085^{\circ} 35^{\prime} \mathrm{W}\right)$ are shown as a means of correlation based on lithologic pattern and biostratigraphy. A. View to the SW from the section. B. View to the west from helicopter. Level 1 (solid yellow line) represents a SB and significant change in carbonate sedimentation from cyclothems and photozoan assemblages below and in two minor cyclothems (yellow dashed lines) above. This is compared to a change in lithology at Usolka (colored stratigraphic column top left). Level 2 is maximum flooding surface of first of two long duration shallowing upward cycles with heterozoan assemblage. Level 2 correlates with FO of of Mesogondolella monstra (M.) and thus the Asselian-Sakmarian boundary; FO of Sweetognathus (Sw.) binodosus is slightly higher. The last occurrence (LO) of Carboniferous holdover taxa including Streptognathodus (St.) and Adetognathus (A.) are shown. Surface 3 is the FO of Sweetognathus asymmetrica and the base of the Artinskian. The thickness between surfaces 1 and 3 is about 170 m. A thin unit of Kungurian is also shown (see Mei et al., 2002) with Neostreptognathodus (N.) pnevi as well as the major latest Kungurian-Roadian transgressive succession of the Van Hauen Formation. 
Sakmarian in the basal part of the Carbon Ridge Formation (Nevada). In California the interval, in which this boundary can be correlated, is within the limits of the fusulinacean zones B and C of the McCloud Limestone (Skinner and Wilde, 1965).

Boardman et al. (2009) demonstrated a zonal breakdown of Upper Carboniferous and Cisuralian based on midcontinent conodonts, including the Streptognathodus barskovi, St. postconstrictus and St. trimulus zones The lower boundary of the St. barskovi Zone coincides with the level of the occurrence of Sweetognathus merrilli. The upper boundary of the St. trimulus Zone is noted by the first occurrence of Sw. whitei.

The Huohongchong section near Ziyun City in Guizhou (Kang et al., 1987) contains Asselian deposits, including beds 17-21, where Mesogondolella striata (according to the author's determination - M. bisselli) and Adetognathus paralautus are recognized. The forms close to Sweetognathus anceps are found in Bed 22 in this section. Probably, this short interval, which includes parts of beds 21 and 22, corresponds to the Asselian-Sakmarian boundary deposits. fusulinaceans obtained in these layers do not contradict this conclusion.

Evidence has emerged that the holotype of Sweetognathus whitei from the Tensleep Sandstone in Wyoming (Rhodes, 1963) represents part of an older lineage and is late Asselian, as indicated by the associated species of Streptognathodus (Henderson, 2018). Sweetognathus whitei is also recovered from the Florence Limestone of the Barneston cyclothem in Kansas in association with abundant Streptognathodus species, and also within the Yaurichumbi Formation in Bolivia (Henderson and Schmitz, pers. comm.; Henderson, 2018). The older lineage is thus marked by Sweetognathus expansus $\rightarrow S w$. merrilli $\rightarrow S w$. whitei. The younger lineage in Russia, which represents an ecologic replacement after the extinction of Streptognathodus, includes Sweetognathus expansus (a long ranging form), $S w$. aff. merrilli $\rightarrow S w$. binodo$s u s \rightarrow S w$. anceps and finally to $S w$. aff. whitei. Sweetognathus merrilli is thus early Asselian, whereas $S w$. aff. merrilli is $3.5 \mathrm{Myr}$ younger occurring near the Asselian-Sakmarian boundary in the southern Urals. The carinal differentiation and pustulose micro-ornament in Sw. merrilli is very irregular in contrast to the regular pattern in $S w$. aff. merrilli. Despite the nomenclatural issue of these two lineages, they are separated in time as determined by strontium isotopes, geochronology, and the co-occurrence of Streptognathodus (Henderson and Schmitz, pers. comm.). The occurrence of the younger lineage in association with a maximum flooding surface and change in stratigraphic character (end of cyclothems) make this an easily recognized natural boundary.

The abundance of conodonts at all levels, noted on the lithologicstratigraphic columns for the Usolka and Kondurovsky sections is from 50 to 100 specimens per $\mathrm{kg}$. However, the abundance of specimens of the shallow-water genus Sweetognathus is much smaller in comparison. This is another reason to choose the Mesogondolella lineage to define the GSSP, rather than the Sweetognathus lineage.

\section{Fusulinaceans}

Fusulinaceans in this section are found at several levels (Fig. 4) (Schmitz and Davydov, 2012), and separated by large intervals, which makes it necessary to use an assemblage of fossil groups for correlation (fusulinaceans, conodonts, miospores), especially given lithologic compositional variations of the deposits.

Fusulinaceans are found only in two levels of the Shikhanian hori- zon in the thin interbeds of fine bioclastic limestone and a level in the Tastubskian (Fig. 4). They mostly belong to the genera Pseudofusulina and Rugosofusulina, which forms the characteristic assemblage in the upper part of the horizon. The almost complete absence of Schwagerina is also noteworthy, as it occurs often in shallow carbonate facies. A few specimens of Sphaeroschwagerina sphaerica were found only in the middle part of Bed 25 (Fig. 4).

In the lower part of the bed 27, there is an impoverished, but important assemblage consisting of Rugosofusulina and Pseudofusulina with the presence of the characteristic Sakmarian species Pseudofusulina verneuili (Moeller) (Fig. 4).

\section{Palynology}

For possible correlation with terrestrial sequences, palynological samples were taken from the Usolka section. Small samples (mass $<200 \mathrm{~g}$ ) were collected and processed using standard techniques (Wood et al. 1996) at the palynological laboratories of the British Geological Survey. The lithologies of the section include limestone, mudstone, shale, limestone breccia and nodules and interbeds of chert.

The 14 samples yielded organic residue including palynomorphs, black equant fragments (probably charcoal or vitrinite) and amorphous organic matter. Palynomorphs were common in several samples, but were universally poorly preserved, showing signs of contemporaneous oxidation so that spore and pollen exine was near colorless and transparent in some cases. Saccate pollen was particularly poorly preserved with sacci commonly separated from corpi. The poor preservation necessitated staining with Safranin O to improve the possibility of determination. Several of the samples contain large numbers of probable algal palynomorphs. These were often marginally better preserved than the terrestrial palynomorphs.

The lower three samples (MPA 56682, 56679 and 56671) yielded the most diverse and best preserved assemblages. This sample range is below the GSSP (Fig. 4). The samples above the GSSP contain only rare, very poorly preserved terrestrial palynomorphs. These samples are dominated by indeterminate non-taeniate and taeniate bisaccate pollen (often detached corpi or sacci). Also present are Vittatina spp. (mainly V. subsaccata). Other taxa recorded include Pteruchipollenites indarraensis, Limitisporites monstruosus, Protohaploxypinus spp., Hamiapollenites fusiformis, Vesicaspora spp. and Striatopodocarpites spp.

A variety of questionable algal forms such as Azonaletes cf. compactus are locally common. A distinct taxon (Algal palynomorph sp. 1) occurring in the upper three samples (MPA 56683, 56667, 56674) is characterized by a complex tight reticulum or tectum.

The presence of poorly preserved terrestrial palynomorphs well below the base of the Sakmarian GSSP, and the absence of significant assemblages above that level makes the palynological succession of Usolka of very limited use for correlation of the GSSP. The best preserved and distinctive palynomorphs in the assemblages are of probable algal origin. Two distinctive forms, Algal palynomorph sp. 1 and sp. 2 occur above the GSSP. Algal palynomorph sp. 1 has a dense reticulate to tectate ornament and Algal palynomorph sp. 2 has a thick punctate wall similar to some forms of Tasmanites. However algal palynomorphs of this type are known to be sensitive to environment (e.g., Stephenson et al., 2004) and are therefore unlikely to have regional or global correlation potential. 


\section{U-Pb Geochronology}

Ramezani et al. (2007) reported four U-Pb zircon ages for ash beds from 29.5 to $36.0 \mathrm{~m}$ at the Usolka section, including ashes bracketing the Permo-Carboniferous boundary between $299.22 \pm 0.13 \mathrm{Ma}$ and $298.49 \pm 0.13 \mathrm{Ma}$, and a younger Asselian ash bed at 298.05 $\pm 0.44 \mathrm{Ma}$. Schmitz and Davydov (2012) subsequently carried out a series of radiometric analyses, based on high-precision, isotope dilution-thermal ionization mass spectrometer (ID-TIMS) U-Pb zircon ages for interstratified ash beds in the southern Urals sections (Fig. 5). Here we provide the results of analysis of two ash-beds from Usolka section, that bracket the Asselian-Sakmarian transition. Zircons of ash beds from the early Asselian Kholodnolozhskian horizon (sample number in Bed 18; 41.25 $\mathrm{m}$ above the base) were analyzed. Nine single grains of zircon yielded a weighted mean ${ }^{206} \mathrm{~Pb} /{ }^{238} \mathrm{U}$ age of $296.69 \pm 0.12 \mathrm{Ma}$. The second studied ash bed in the section (Bed 28; $66.2 \mathrm{~m}$ above base) relates to the Sakmarian; a number of equant zircons from this ash sample gave a weighted mean of ${ }^{206} \mathrm{~Pb} /{ }^{238} \mathrm{U}$ date of $291.10 \pm 0.12 \mathrm{Ma}$ for eight crystals, excluding three antecrysts (Schmitz and Davydov, 2012). The extrapolated age for bed $26 / 3$ at $55.4 \mathrm{~m}$ is $293.52 \pm 0.17 \mathrm{Ma}$ produced by a Monte Carlo simulation (Fig. 4).

\section{Chemostratigraphy}

\section{Strontium Isotopes}

The ability to date and correlate sediments using $\mathrm{Sr}$ (strontium) isotope ratios $\left({ }^{87} \mathrm{Sr} /{ }^{86} \mathrm{Sr}\right.$ ) has been demonstrated (Veizer et al., 1999; McArthur et al., 2012). Schmitz et al. (2009) in a presentation at the International Conodont Symposium indicated a consistent secular trend of ${ }^{87} \mathrm{Sr} /{ }^{86} \mathrm{Sr}$ isotopic values from conodont elements with a low CAI through the Early Permian. The ${ }^{87} \mathrm{Sr}{ }^{86} \mathrm{Sr}$ isotopic value for the base-Sakmarian was approximately 0.70787 based the isotopic analyses by TIMS (Schmitz et al., 2009). This value is generally consistent with that shown in the Permian profile (McArthur et al., 2012) and South China (Wang et al., 2018). Korte and Ullmann (2018) displayed a first-order Permian ${ }^{87} \mathrm{Sr} /{ }^{86} \mathrm{Sr}$ trend based on reviewing existing data including brachiopod, conodont, evaporite and bulk carbonate samples. However, the conodont data in Asselian-Sakmarian interval of their composite curve are rare. Strontium isotopes from individual conodont elements have been integrated with geochronologic ages to produce a time model here. The strontium isotopic composition of seawater at the base of the Sakmarian Stage is now calculated at ${ }^{87} \mathrm{Sr} r{ }^{86} \mathrm{Sr}=0.70787$ (Fig. 11).

\section{Carbon Isotope Chemostratigraphy}

Carbon isotope chemostratigraphy around the Carboniferous and Permian boundary at the Usolka section was previously studied by Nelson and Ritter (1999) and Mii (2001). A group of Chinese researchers conducted a broader study of stable carbon and oxygen isotopes in south Urals sections - Usolka, Dal'ny Tulkas and Kondurovsky (Zeng et al., 2012). The basic results, obtained at the Usolka section are of interest to this proposal (Figs. 4).

1. A gradually increasing trend in carbonate carbon isotope $\left(\delta^{13} \mathrm{C}_{\text {carb }}\right)$ values has been documented in the interval from the base of the Asselian to the lower Sakmarian at the Usolka section. This is generally consistent in timing with the increasing trend of Glacial III or P1 from the latest Carboniferous to early Sakmarian that prevailed in southern Gondwana (Zeng et al., 2012) (Fig. 5).

2. An excursion with double negative shifts in $\delta^{13} \mathrm{C}_{\text {carb }}$ value is documented around the Asselian/Sakmarian boundary at the Usolka section (Fig. 4) and a more or less similar pattern is present at the Kondu-

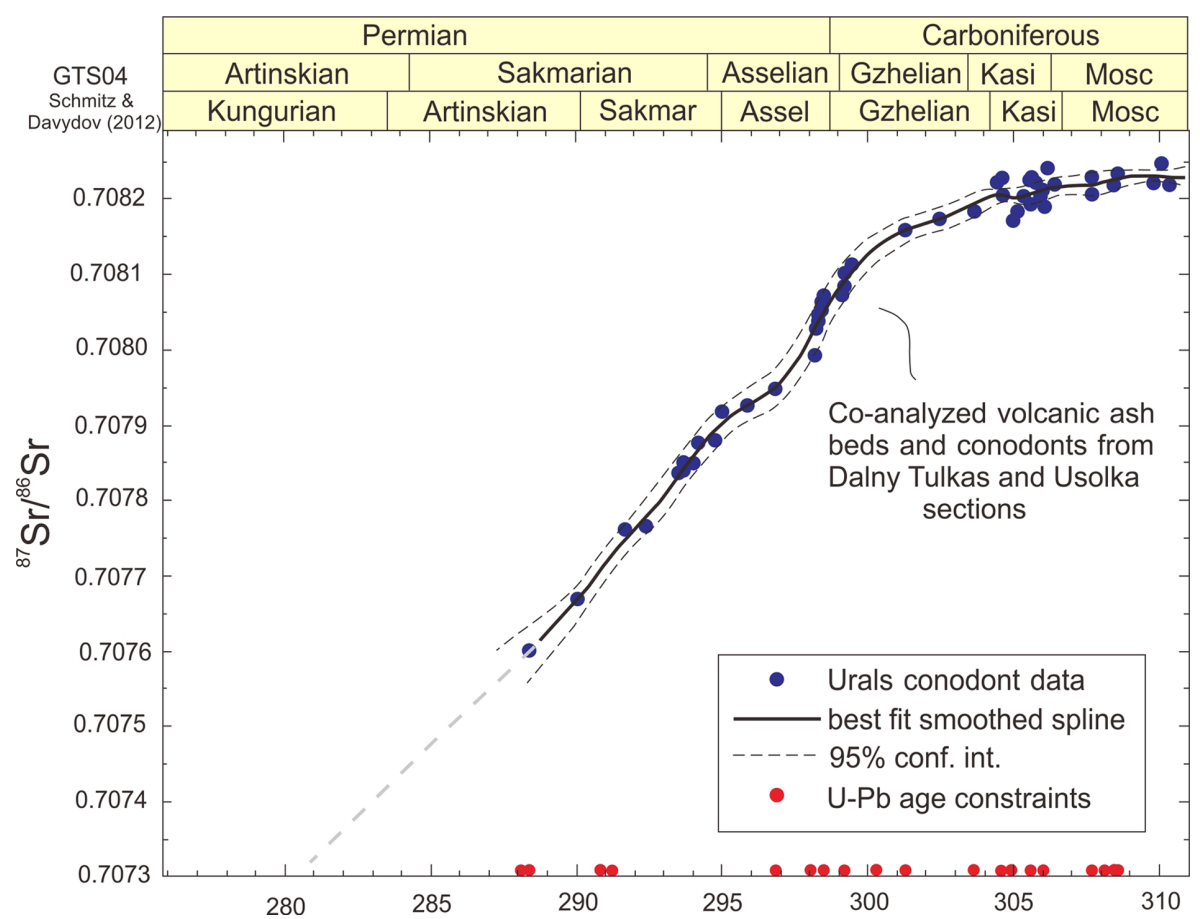

Figure 11. Age model for Sr-isotopic work by Mark Schmitz at the Dalny Tulkas and Usolka sections in southern Urals (modified from Henderson et al., 2012). rovsky section as well (Zeng et al., 2012). The second negative excursion is nearly consistent with the FAD of Mesogondolella monstra at the Usolka section (Fig. 5). This excursion may have potential to serve as a chemostratigraphic marker for intercontinental correlation (Zeng et al., 2012). However, the $\delta^{13} C_{\text {carb }}$ positive shift after the GSSP is minor, and more work in different areas is necessary to confirm its correlation value.

\section{Why use the FAD of Mesogondolella monstra?}

The original GSSP position under consideration was at the base of bed $25 / 3$ at $51.6 \mathrm{~m}$ using the FAD of Mesogondolella uralensis or Sweetognathus aff. merrilli as the definition of the Sakmarian-base GSSP (Chuvashov et al., 2002; Chernykh et al., 2013). There are at least three problems with this position: 1) The point is at the base of a coarse-grained event bed, which may have reworked or concentrated 


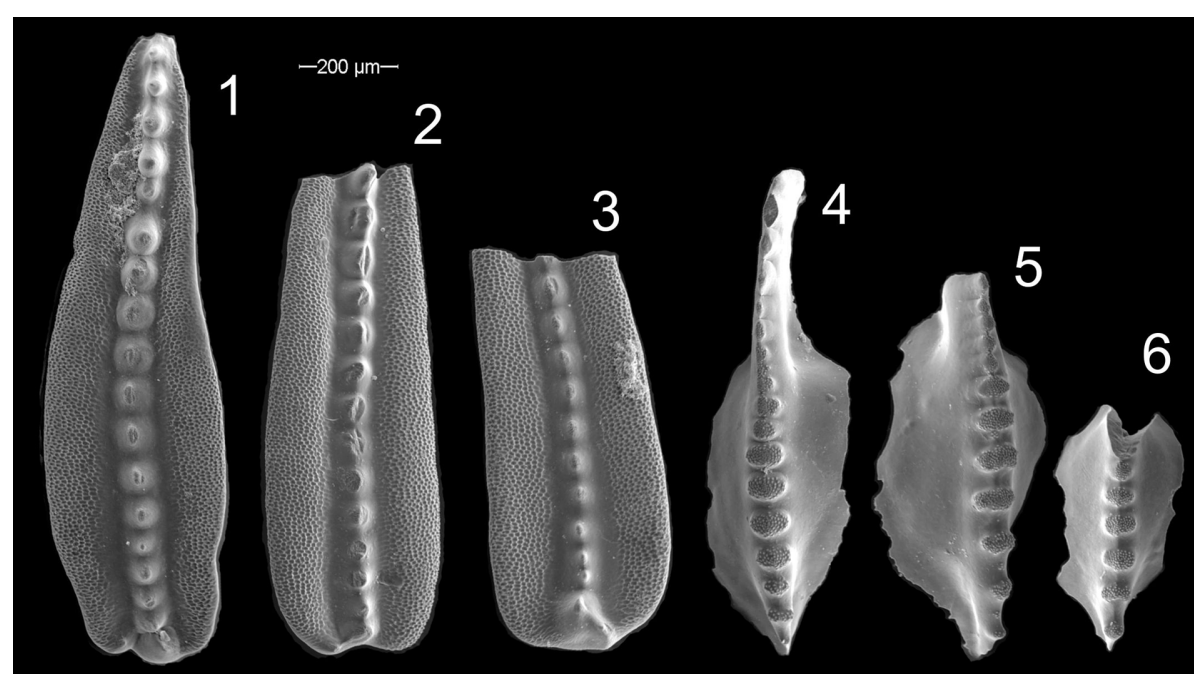

Figure 12. Conodonts around the base of Sakmarian at Carlin Canyon in northern Nevada, USA. 1. Mesogondolella monstra (transitional? with M. striata), Sample 684; 2. M. monstra, Sample 684; 3. M. monstra (transitional? with M. obliquimarginata, Sample 685; 4. Sweetognathus binodosus, Sample 685; 5. Sw. binodosus, Sample 685; 6. Sw. binododus, Sample 684. Material is from the unpublished MSc thesis of Elinda Dehari at the University of Calgary. Sample 685 is about $2 \mathrm{~m}$ higher than Sample 684 in a section that is several hundred metres thick; both are from the lower Buckskin Mountain Formation. These specimens occur above the last Streptognathodus in the section including St. fusus and St. postfusus.

conodonts and not within the dominant background sedimentation of thin-bedded carbonate mudstone. 2) Mesogondolella uralensis has not yet been recognized outside of the Uralian region. 3) The lack of taxonomic clarity with Sweetognathus aff. merrilli. A higher position that provides good correlation between the Urals and North America is the first appearance of Mesogondolella monstra or Sweetognathus binodosus in Bed 26/3 at $55.4 \mathrm{~m}$. Mesogondolella manifesta occurs above this level. A few specimens from Carlin Canyon in northern Nevada are herein provided to compare to the Uralian material (Fig. 12). These specimens come from the lower Buckskin Mountain Formation, which was deposited as a long-duration third-order sequence above cyclothems of the Strathearn Formation. Similar material has been recovered in western Canada and the Sverdrup Basin in the Canadian Arctic. This appears to be the first level in the "Sakmarian" in which Mesogondolella species compare well, it is close to the traditional fusulinacean level, and probably indicates interregional migration of taxa associated with the near-termination of P1 glaciation and a maximum flooding surface that changes the character of sedimentation. This position is close to, but above the extinction of Streptognathodus. In other words, the taxonomic changeover of conodonts at this level is comparable with many other regions in the world.

Mesogondolella uralensis and M. monstra are both offshore conodont species and have a distribution that should be wider than Sweetognathus aff. merrilli and Sw. binodosus, which are "shallow-water" conodont species. In fact, Sw. aff. merrilli was reported from the Urals (Chernykh, 2005; 2006), and Sw. merrilli has been reported from New Mexico (Kozur and Lemone, 1995), western Canada (Moore et al., 1998), Kansas (Boardman et al., 2009), Central Iran (Leven and Gorgij, 2011) and North China (Gao et al., 2005). Sweetognathus binodosus was reported from the Urals (Chernykh, 2005; 2006), West Texas (Davydov et al., 2005), western Canada (Zubin-Stathopoulos et al., 2013), Nevada (Wardlaw et al., 2015) and Central Iran (Balini et al., 2015), but Mesogondolella uralensis has only been reported from the Urals (Chernykh et al., 2016). Mesogondolella monstra has a relatively wide distribution, including, at least, the Urals (Chernykh, 2005; 2006), Nevada (Chernykh et al., 2016), Central Iran (Balini et al., 2015) and Thailand (as M. cf. monstra) (Metcalfe et al., 2017), and is a deep-water species that can provide correlation between the Paleotethys and western North America.

Table 1. A summary of evaluation for the GSSP section at Usolka

Requirements for the GSSP section

Continuity of the sedimentation

Usolka Section

The continuity of the section has been testified by the continuous conodont phylogenetic lineages, abundant fusulinaceans and no sedimentary structures showing hiatuses from Upper Carboniferous to Asselian and Sakmarian stages of the Cisuralian

Completeness of the exposed section and its sufficient thickness

The total thickness of section from Kasimovian to the Sakmarian comprises more than $70 \mathrm{~m}$ thick strata. They are practically $100 \%$ exposed

\begin{tabular}{l} 
Major fossil groups \\
\hline Metamorphism and structural transformations of rocks \\
\hline Structural unconformities, breaks \\
\hline $\begin{array}{l}\text { Possibility of studying the section by the magnetostratigraphic, } \\
\text { chemostratigraphical and geochronologic methods }\end{array}$
\end{tabular}
Fusulinaceans, ammonoids, conodonts No metamorphism and structural-lithological transformations of rocks None

Magnetostratigraphy is not studied because the GSSP interval is within the long-term stable Kiaman Reverse Superchron with no polarity zone. $\delta^{13} \mathrm{C}_{\text {carb }}$ profile has been published. Volcanic ash beds are abundant in the Gzhelian (4 layers), Asselian (4 layers) and Sakmarian (3 layers) parts of the section. Highprecision ID-TIMS dates are available at the GSSP section

Accessibility of section for the visit and the study and its guaranteed safety

There is good road for tourists to get to the GSSP section near a spa recreation area. Accessibility of section for the visit is available at any time by car. Safety is guaranteed by the government of Bashkortostan 


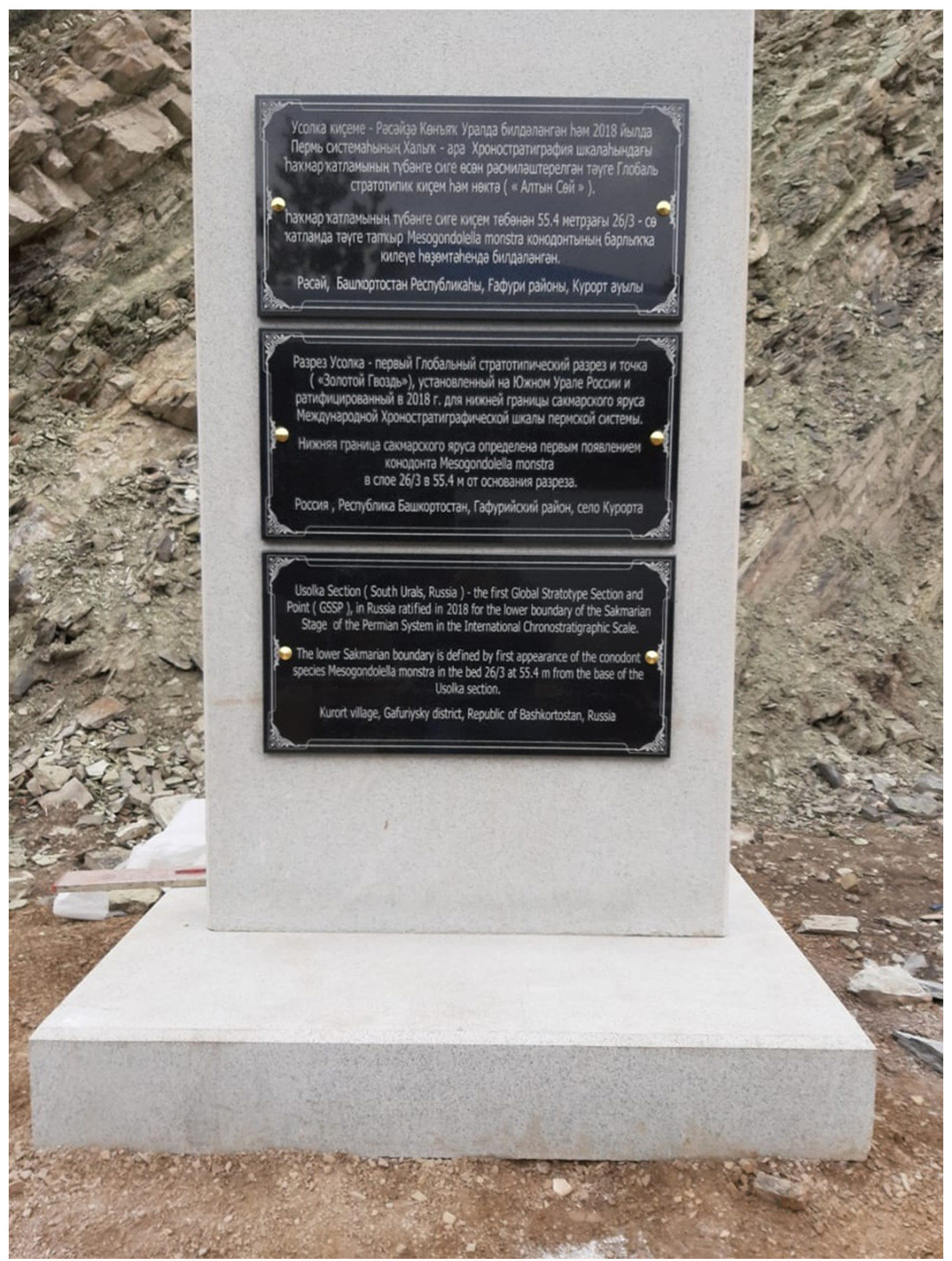

Figure 13. The GSSP monument established at the Usolka section in southern Urals, Russia

\section{Summary}

We define the base of the Sakmarian Stage at a point indicated by the FAD of Mesogondolella monstra in Bed $26 / 3$ at $55.4 \mathrm{~m}$ of the Usolka section in southern Urals, Russia. An extrapolated geochronologic age of $293.52 \pm 0.17 \mathrm{Ma}$, strontium isotope value near 0.70787 , and two negative excursions in $\delta^{13} \mathrm{C}_{\text {carb }}$ value, one at or just below the boundary and the other is slightly lower, serve as additional markers to correlate the boundary. Furthermore, Sweetognathus binodosus appears at the defined boundary and other fossils including fusulinaceans provide additional data to assist correlation. The Usolka section meets the requirements for a GSSP section (Table 1) and a monument has been estab- lished (Fig. 13). In addition, the section has been protected by the Russian government.

\section{Acknowledgement}

We thank Ueno Katsumi and Spencer Lucas for their very careful review and numerous comments by associate editor Lucia Angiolini, which were very useful to improve the manuscript. SZS and DXY's work is supported by the Strategic Priority Research Programs of the Chinese Academy of Sciences (XDB26000000, XDB18000000) and CMH by an NSERC Discovery Grant. M.H.S. published with the per- 
mission of the Director of the British Geological Survey.

\section{References}

Balini, M., Mandrioli, R., Nicora, A., Angiolini, L., Vuolo, I., Sohrabi, Z., and Bahramanesh, M., 2015, First report of Upper Pennsylvanian ammonoids and Lower Permian conodonts from Bagh-e-Vang area (Central Iran). Permophiles, v. 62, pp. 25-27.

Beauchamp, B., and Henderson, C.M., 1994, The Lower Permian Raanes, Great Bear Cape and Trappers Cove formations, Sverdrup Basin, Canadian Arctic; stratigraphy and conodont zonation. Bulletin of Canadian Petroleum Geology, v. 42, pp. 562-597.

Beauchamp, B., Calvo Gonzalez, D., Henderson, C.M., Baranova, D.V., Wang, H.Y., Pelletier, E., accepted (in press for 2020). Late Pennsylvanian - Early Permian tectonically-driven stratigraphic sequences and carbonate sedimentation along northern margin of Sverdrup Basin (Otto Fiord Depression), Arctic Canada. In Henderson, C.M., Ritter, S., and Snyder, W.S. (eds.), Late Paleozoic Tectono-stratigraphy and Biostratigraphy of western Pangea. SEPM Special Publication No. 113, 10.2110/sepmsp. 113.

Boardman, D.R., Wardlaw, B.R., and Nestell, M.K., 2009, Stratigraphy and conodont biostratigraphy of the uppermost Carboniferous and Lower Permian from the North American Midcontinent. Kansas Geological Survey Bulletin, v. 255, pp. 1-42.

Chernykh, V.V., 2005, Zonal method in biostratigraphy, zonal conodont scale of the Lower Permian in the Urals. Institute of Geology and Geochemistry of RAN, Ekaterinburg, $217 \mathrm{p}$.

Chernykh, V.V., 2006, Lower Permian conodonts in the Urals. Institute of Geology and Geochemistry, Uralian Branch of the Russian Academy of Sciences, Ekaterinburg, 130 p.

Chernykh, V.V., Chuvashov, B.I., Davydov, V.I., Schmitz, M., and Snyder, W.S., 2006, Usolka section (southern Urals, Russia): a potential candidate for GSSP to define the base of the Gzhelian Stage in the global chronostratigraphic scale. Geologija, v. 49, pp. 205-217.

Chernykh, V.V., Chuvashov, B.I., Shen, S.Z., and Henderson, C.M., 2013, Proposal for the Global Stratotype Section and Point (GSSP) for the base-Sakmarian Stage (Lower Permian). Permophiles, v. 58, pp. 16-26.

Chernykh, V.V., Chuvashov, B.I., Shen, S.Z., and Henderson, C.M., 2016, Proposal for the Global Stratotype Section and Point (GSSP) for the base-Sakmarian Stage (Lower Permian). Permophiles, v. 63, pp. 4-18.

Chuvashov, B.I., Chernykh, V.V., Davydov, V.I., and Pnev, V.P., 1991a, Sakmarian Stratotype-Kondurovsky, International Congress "Permian System of the World". Guide of the geological excursions, Sverdlovsk, pp. 4-31.

Chuvashov, B.I., Chernykh, V.V., Davydov, V.I., and Pnev, V.P., 1993, Kondourovsky section. In: Chermynkh, V.A., Chernykh, V., Chuvashov, B.I., Kopnin, V.J., Molin, V.A., Ozhgibesov, V.P., and Sofronitsky, P.A. (Eds.), Permian System: Guides to Geological Excursions in the Uralian Type Localities, Occasional Publications ESRI, New Series, No. 10. Uralian Branch, Russian Academy of Sciences and the Earth Sciences and Resources Institute, University of South Carolina, Ekaterinnurg, Columbia, pp. 102-119.

Chuvashov, B.I., Chernykh, V.V., Leven, E.Y., Davydov, V.I., Bowring, S.A., Ramezani, J., Glenister, B.F., Henderson, C.M., Schiappa, T.A., Northrup, C.J., Snyder, W.S., Spinosa, C., and Wardlaw, B.R., 2002, Proposal for the base of the Sakmarian Stage: GSSP in the Kondurovsky Section, Southern Urals, Russia. Permophiles, v. 41, pp. 4-13.

Chuvashov, B.I., Dupina, G.V., Mizens, G.A., and Chernykh, V.V., 1991b, Krasnousol'skiy section, International Congress "Permian System of the World". Guide of the geological excursions, Part II. Issue I, Sverdlovsk, pp. 5-48.

Davydov, V.I., Leven, E.Y., and Chuvashov, B.I., 1999, Fusulinid Biostratigraphy in Asselian/Sakmarian Transition in Stratotype Area Southern Urals, Russia. Permophiles, v. 35, pp. 30-31.
Davydov, V.I., Schmitz, M.D., Snyder, W.S., and Wardlaw, B.R., 2005, Progress toward development of the Cisuralian (Lower Permian) timescale (biostratigraphy, chronostratigraphy, radiometric calibration). The Nonmarine Permian, New Mexico Museum of Natural History and Science Bulletin, v. 30, pp. 48-55.

Davydov, V.I., Zinder, W.S., and Spinosa, C., 1997, Upper Paleozoic fusulinacean biostratigraphy of the southern Urals. Permophiles, v. 30, pp. 11-14.

Fielding, C.R., Frank, T.D., and Isbell, J.L., 2008, The Late Paleozoic ice age-A review of current understanding and synthesis of global climate patterns. Geological Society of America Special Papers, v. 441, pp. 343-354.

Gao, L.F., Ding, H., and Wan, X.Q., 2005, Taxonomic revision of conodont Sweetognathus species in the uppermost Taiyuan Formation, Yuhuai Basin and its significance. Acta Micropalaeontologica Sinica, v. 22, pp. 370-382.

Henderson, C.M., 2018, Permian conodont biostratigraphy. Geological Society, London, Special Publications, v. 450, pp. 119-142.

Henderson, C.M., Wardlaw, B.R., Davydov, V.I., Schmitz, M.D., Schiappa, T.A., Tierney, K.E., and Shen, S.Z., 2012, Proposal for base-Kungurian GSSP. Permophiles, v. 56, pp. 8-21.

Isbell, J.L., Miller, M.F., Wolfe, K.L., and Lenaker, P.A., 2003, Timing of Late Paleozoic glaciation in Gondwana: was glaciation responsible for the development of northern hemisphere cyclothems? Geological Society of America Special Papers, v. 370, pp. 5-24.

Kang, P.Q., Wang, C.Y., and Wang, Z.H., 1987, Carboniferous-Permian conodont biostratigraphy in the shelf facies of Ziyun County, Guizhou. Acta Micropalaeontologica Sinica, v. 4, pp. 179-194.

Korte, C., and Ullmann, C.V., 2018. Permian strontium isotope stratigraphy. In: Lucas, S.G., and Shen, S.Z. (Eds.), the Permian Timescale. Geological Society, London, Special Publications, v. 450, pp. 105-118.

Kozur, H.W., and Lemone, D.V., 1995, The Shalem Colony section of the Abo and upper Hueco members of the Hueco Formation of the Robledo Mountains, Dona Ana County, New Mexico; stratigraphy and new conodont-based age determinations; Early Permian footprints and facies. Bulletin New Mexico Museum of Natural History and Science, v. 6, pp. 39-55.

Leven, E.J., and Gorgij, M.N., 2011, First record of Gzhelian and Asselian Fusulinids from the Vazhnan Formation (Sanandaj-Sirjan zone of Iran). Stratigraphy and Geological Correlation, v. 19, pp. 486-501.

McArthur, J.M., Howarth, R.J., and Shields, G.A., 2012, Strotium isotope stratigraphy. In: Gradstein, F.M., Ogg, J.G., Schmitz, M.D., and Ogg, G.M. (Eds.), The Geological time scale 2012. Elsevier, Amsterdam, pp. $127-144$.

Mei, S.L., Henderson, C.M., and Wardlaw, B.R., 2002, Evolution and distribution of the conodont Sweetognathus and Iranognathus and related genera during the Permian, and their implications for climate changes. Palaeogeography Palaeoclimatology Palaeoecology, v. 180, pp. 57-91.

Metcalfe, I., Henderson, C.M., and Wakita, K., 2017, Lower Permian conodonts from Palaeo-Tethys Ocean Plate Stratigraphy in the Chiang MaiChiang Rai Suture Zone, northern Thailand. Gondwana Research, v. 44, pp. 54-66.

Mii, H.S., 2001, Isotopic records of brachiopod shells from the Russian Platform - evidence for the onset of mid-Carboniferous glaciation. Chemical Geology, v. 175, pp. 133-147.

Moore, D.B., Henderson, C.M., Karel, W., Reimer, J., Uffen, D., and Ravlich, M., 1998, Sequence biostratigraphy in a tectonically active region; correlating across the Sukunka Uplift, the Belloy Formation, and the Spray Lakes and Ishbel groups.; Geo-Triad '98 abstracts, plenary oral posters core workshop; rocks, risk and reward. Geo-triad, v. 98, pp. 28-29.

Nelson, S.T., and Ritter, S.M., 1999, A large carbon isotope anomaly at the Carboniferous-Permian boundary: the Usolka River section of Russia. Permophiles, v. 33, pp. 19-21.

Ramezani, J., Schmitz, M.D., Davydov, V.I., Bowring, S.A., Snyder, W.S., and Northrup, C.J., 2007, High-precision U-Pb zircon age constraints 
on the Carboniferous-Permian boundary in the southern Urals stratotype. Earth and Planetary Science Letters, v. 256, pp. 244-257.

Ramezani, J., and Bowring, S.A., 2018, Advances in numerical calibration of the Permian timescale based on radioisotopic geochronology. Geological Society, London, Special Publications, v. 450, p. 51-60.

Rhodes, F.H.T., 1963, Conodonts from the topmost Tensleep sandstone of the eastern Big Horn Mountains, Wyoming. Journal of Paleontology, v. 37, n. 2, pp. 401-408.

Schiappa, T.A., 1999, Lower Permian (Asselian-Sakmarian) stratigraphy and biostratigraphy (ammonoid and conodont) of Novogafarovo and Kondurovsky, southern Ural Mountains, Russia, University of Idaho, $200 \mathrm{p}$.

Schmitz, M.D., and Davydov, V.I., 2012, Quantitative radiometric and biostratigraphic calibration of the Pennsylvanian-Early Permian (Cisuralian) time scale and pan-Euramerican chronostratigraphic correlation. Geological Society of America Bulletin, v. 124, pp. 549-577.

Schmitz, M.D., Davydov, V.I., and Snyder, W.S., 2009, Permo-Carboniferous Conodonts and Tuffs: High precision marine Sr isotope geochronology. Permophiles, Supplement 1(53), p. 48.

Shen, S.Z., Zhang, H., Zhang, Y.C., Yuan, D.X., Chen, B., He, W.H., Mu, L., Lin, W., Wang, W.Q., Chen, J., Wu, Q., Cao, C.Q., Wang, Y., and Wang, X.D., 2019, Permian integrative stratigraphy and timescale of China. Science China Earth Sciences, v. 62, p. 154-188.

Skinner, J.W., and Wilde, G.L., 1965, Permian biostratigraphy and fusulinid faunas of the Shasta Lake area, northern California. The University of Kansas, Paleontological Contributions, Article 6, p. 1-98.

Stephenson, M.H., Williams, M., Leng, M.J., and Monaghan, A. 2004, Aquatic plant microfossils of probable non-vascular origin from the Ballagan Formation (Lower Carboniferous), Midland Valley, Scotland. Proceedings of the Yorkshire Geological Society, v. 55, pp. 145-158.
Veizer, J., Ala, D., Azmy, K., Bruckschen, P., Buhl, D., Bruhn, F., Carden, G.A.F., Diener, A., Ebneth, S., Godderis, Y., Jasper, T., Korte, C., Pawellek, F., Podlaha, O.G., and Strauss, H., $1999,{ }^{87} \mathrm{Sr}{ }^{86} \mathrm{Sr}, \delta^{13} \mathrm{C}$ and $\delta^{18} \mathrm{O}$ evolution of Phanerozoic seawater. Chemical Geology, v. 161, pp. 59-88.

Wang, W.Q., Garbelli, C., Zheng, Q.F., Chen, J., Liu, X.C., Wang, W., and Shen, S.Z. 2018, Permian ${ }^{87} \mathrm{Sr} /{ }^{86} \mathrm{Sr}$ chemostratigraphy from carbonate sequences in South China: Palaeogeography, Palaeoclimatology, Palaeoecology, v. 500, pp. 84-94.

Wardlaw, B.R., and Davydov, V.I., 2000, Preliminary placement of the international Lower Permian working standard to the Glass Mountains, Texas. International Commission on Stratigraphy International Union of Geological Sciences, p. 11.

Wardlaw, B.R., Gallegos, D.M., Chernykh, V.V., and Snyder, W.S., 2015, Early Permian conodont fauna and stratigraphy of the Garden Valley formation, Eureka County, Nevada. Micropaleontology, v. 61, pp. 369 387.

Wood, G.D., Gabriel, A.M., and Lawson, J.C. 1996, Palynological techniques - processing and microscopy. In: Jansonius, J. and McGregor, D.C. (eds.), Palynology: Principles and Applications. American Association of Stratigraphical Palynologists Foundation, 1, pp. 29-50.

Zeng, J., Cao, C.Q., Davydov, V.I., and Shen, S.Z., 2012, Carbon isotope chemostratigraphy and implications of palaeoclimatic changes during the Cisuralian (Early Permian) in the southern Urals, Russia. Gondwana Research, v. 21, pp. 601-610.

Zubin-Stathopoulos, K.D., Beauchamp, B., Davydov, V.I., and Henderson, C.M., 2013, Variability of Pennsylvanian-Permian Carbonate Associations and implications for NW Pangea Palaeogeography, east-central British Columbia, Canada. Geological Society, London, Special Publications, v. 376, pp. 47-72.

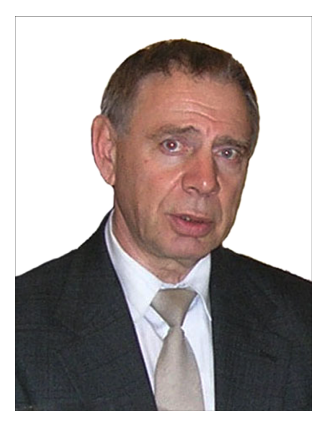

Valerie V. Chernykh received his $\mathrm{Ph}$. D. from the Mining Institute of the Geological Faculty in Swerdlovsk. He has worked in the Institute of Geology and Geochemistry of the Ural Branch of the Russian Academy of Science since 1981 . He presently holds the position of leading scientist in the Laboratory of Stratigraphy and Paleontology. His research interests include evolutionary biology, micropaleontology, general and applied stratigraphy. More recently his research focuses on the Permian stratigraphy and micropaleontology of the Ural Mountains. He has published more than 200 works, including 7 monographs.

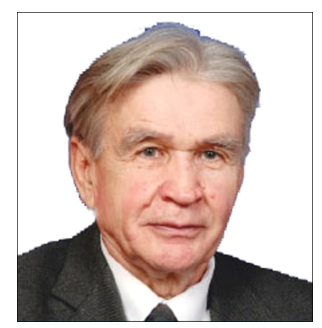

Boris I. Chuvashov got his Ph.D. of geology and mineralogy in 1980 . He has been the corresponding member of the Russian Academy of Sciences since 1994. Since 1960, he has worked at the Institute of Geology and Geochemistry, Ural Branch of the Russian Academy of Sciences. He was the head of the Laboratory of Stratigraphy and Paleontology between 1982-2008. His main researches are devoted to the paleontology of foraminifera and algae, the geology of the Upper Paleozoic sediments of the Urals. He has published more than 400 works, including 10 monographs.

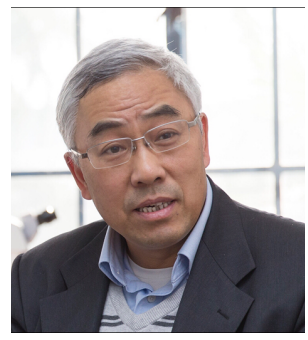

Shu-Zhong Shen is a Professor at School of Earth Sciences and Engineering of Nanjing University. His primary researches are on the Permian stratigraphy, brachiopods, the end-Permian mass extinctions and palaeoenvironmental changes. He was elected an academician of Chinese Academy of Sciences in 2015. He has been the chair of the International Subcommissionon on Permian Stratigraphy since 2012 and the elected ICS Vice-chair from late 2020.



Charles M. Henderson is a Professor at the University of Calgary where he has taught stratigraphy and paleontology since 1989 . His primary research is on the biostratigraphy of Permian and Early Triassic conodonts around the world, including in arctic and western Canada, China, Oman, Bolivia, Russia, and the United States. His research is focused on completion of a global chronostratigraphic subdivision of the Permian System. He is a Fellow of The Royal Canadian Geographical Society and the Geological Society of America and former Chairman of the Subcommission on Permian Stratigraphy, ICS. 


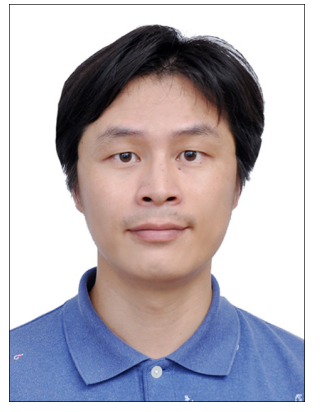

Dong-Xun Yuan is an assistant research professor at Nanjing Institute of Geology and Palaeontology, Chinese Academy of Sciences. He got his Ph.D. in geology of Nanjing University in 2015 and a postdoctoral fellow at University of Calgary, Canada from 2016 to 2017. His primary research focuses on Permian conodonts, biostratigraphy, paleobiogeography and global correlation.

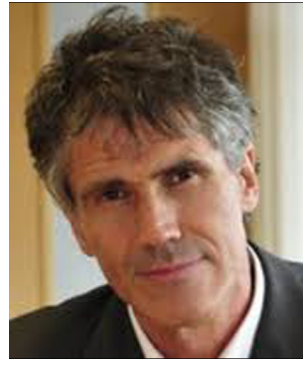

Michael H. Stephenson is Executive Chief Scientist and professor (Decarbonisation) at the British Geological Survey. He has done research in the Middle East and Asia, including in Oman, Saudi Arabia, Jordan, Pakistan, Iran, Israel and Iraq. He has professorships at Nottingham and Leicester universities in the UK and is a visiting professor at the University of Nanjing, China. He has published three books and over 100 peer-reviewed papers. His recent book 'Energy and Climate Change: An Introduction to Geological Controls, Interventions and Mitigations' examines the Earth system science of the formation and use of fossil fuel resources, and the implications for climate change. 